Rev. Yves-Marie Lequin Theological Faculty of Nice Sophia-Antipolis

\title{
"Why have I become a burden to you?" Disability and Holiness: A Reading of Job 7:20
}

This article explores disability and holiness in light of the neutral theme of burden as it appears in the Book of Job. Job is afflicted by evil and is revolted by it; yet, he ends up accepting this mystery. Job's example expands the definition of "holiness" to include one of its key elements: the gift of a word of freedom that can give rise to prophetic vulnerability.

Key words: disability, burden, holiness, Job, vulnerability, struggle.

Is the need to depend on others that physical suffering causes what essentially defines disability? This kind of suffering is caused by a limited ability to participate in social life, due to one or more physical or mental limitations that may be permanent or, as in the case of a sickness, temporary.

The notion of dependence is important. For, the disabled frequently participate in social life only with the help of certain aids such as prostheses, which require significant rehabilitation; the (sometimes) permanent assistance of an aid or nurse; medication, which can have terrible side effects; etc.

It is clear that disabilities do not cease to exist once a person who is disabled has been integrated into equal participation in society, although the expression "handicap" would make it seem so. The word "handicap" comes from the game "hand-in-cap." The aim this game was to have an umpire equal the so-called "playing field" in horse racing by placing a load on horses that performed better. The umpire would choose the weight of load. The load would subsequently slow faster horses down and, thereby, equalize the slower horses' chance of winning. Like these horses (but far different because they are human), 
Theology of Spirituality

those who have disabilities still experience objective suffering, even in the best circumstances, and an evil that requires special attention. Suffering also places the one who is afflicted on the margins of society. In addition to isolation, the one who suffers often experiences rejection and is considered a freak.

Although certain laws have taken into account the suffering, dependence, and rejection that the disabled experience, ${ }^{1}$ people should still remain aware and even critical of the fact that many people who are not disabled tend to deny the suffering that accompanies disability by thinking that simply changing the way disabled people perceive their situation or adapt to the environment would eliminate their suffering. ${ }^{2}$

The Book of Job is the story of a man who is stricken by many terrible calamities and maladies. The story serves as a striking illustration of the isolation caused by suffering. In his agony, Job turns to God, is met with silence, and feels that God is treating him unjustly. Job is disabled and cut off from society, so much so that even his own wife rejects him: "My relatives have failed me... My close friends have forgotten me... I have become a foreigner in their eyes... My breath is offensive to my wife... All my intimate friends abhor me and those whom I loved have turned against me" (Job 19:13-19). ${ }^{3}$ Job's friends come to him and try to convince him that he is suffering because he has committed a serious evil that has called down God's wrath upon him. This explanation is a way to reintegrate Job into society by assigning him a place as a sign and even proof of divine justice. Job, however, rejects this explanation and what he considers to be injustice. His so-called "friends" are nothing more than "whitewashers of lies, worthless physicians" (13:4).

It does not make sense to reject the fact that neither wisdom nor science can explain certain things. This insight from 2,500 years ago is still valid and remains all the more interesting today because it applies to the seemingly contradictory connection between Job's holiness and his suffering, which essentially relegates him to a state of suspended death that makes him unfit for life.

One short passage from Job is particularly interesting. In his isolation, Job sees himself as a burden, and he asks God: "Why have I

$1 \quad$ N. Maggi-Germain, "La construction juridique du handicap," Droit social 12(2002).

This article quotes the Holy Bible: New Revised Standard Version Catholic Edition (NRSVCE), Oxford 2001. Otherwise, biblical passages have been translated by the author. 
become a burden to you?"(7:20). The Hebrew term used here is maśśa', which has two meanings. On the one hand, the word means "burden," "charge," "yoke," or even "handicap." This recalls the aforementioned expression "hand-in-cap," which refers to the load placed on the better performing racehorses in order to ensure that the poorer performing horses have equal opportunity to win. This expression eventually became "handicap" to refer to someone with a form of infirmity. Maśśa' also means "oracle," particularly as in naśa' maśśa' (א. burden (to place it on someone)." The oracle is the word of God ${ }^{5}$ and teaching and studying the word (doctrine) are the burden (hence the alternate meaning of maśśa" is "instruction"). The Book of Sirach says the following about those who are foolish and reject the discipline of wisdom: "He cannot remain with her. She will be like a heavy stone to test them, and they will not delay in casting her aside" $(6: 21){ }^{6}$

In the question "Why have I become a burden to you?," Job plays on the word maśśa' and offends God twice: First, by claiming that he is a burden to God-that he is God's "handicap" or "load." In: this way, he implies the first falsehood that God, the Almighty, is somehow weak or can be burdened by anyone. Second, Job erroneously claims that he himself is as an oracle addressed to God-the Word Himself, or a prophetic word sent out from God and back to Him. According to this logic, Job instructs God, who transcends all wisdom.

An interesting parallel exists between the Book of Job and a specific scene from Aeschylus' Greek tragedy Prometheus Bound. In the play, the hero whom the gods condemn to torture cries out "Alas!" in his

4 2Kings 9:25: "the Lord uttered (naśa') this oracle (maśśa') against him," (הְָּה

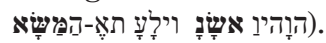

5 G. Lambert, "Mon joug est aisé et mon fardeau léger," Nouvelle Revue Théologique (NRT) 77, 9(1955): 965: "II importe de se souvenir ici que, dans la pensée des Hébreux, un oracle n'était pas seulement une, proclamation qui annonçait un événement futur. La, prophétie est parole de Dieu, elle ne revient pas à lui sans avoir produit son effet. Elle est efficiente de l'événement qu'elle annonce. Par là même, elle possède une force contraignante qui- pèse sur la vie de ceux qu'elle concerne. En ce sens, elle est un fardeau, une charge et l'on comprend ainsi le passage du sens propre au-sens métaphorique, de la signification de fardeau à celle d'oracle." English translation: "It is important to remember here that, according to Hebrew thought, an oracle was not just a proclamation that foretold a future event. Prophecy is the word of God; it does not return to him void. Prophecy effects the event it announces. For the same reason, it is a binding force that affects the lives of those it concerns. In this sense, it is a burden-a load-and we thus understand the movement from the proper meaning to the metaphorical meaning, from the meaning of burden to that of oracle."

Ibid., 967. 
Theology of Spirituality

suffering as a poor mortal. Hermes responds with contempt: "Alas, that Zeus knows not that word, Alas!," thus affirming the superiority of the eternal and wise gods who know no suffering. Prometheus defiantly answers him: "But ageing Time teacheth all knowledge!" 7 The gods do not know everything.

The Book of the Prophet Jeremiah contains the same type of irony in the man versus the gods debate. The people ask the Jeremiah, "What is the Lord's oracle?" In light of the double meaning of the word maśśa', the text could also be understood to say: "What is the burden of the Lord?" or "What burden are you still going to impose on us in the name of the Lord?" Annoyed, God responds through Jeremiah: "You are the burden" (23:33-38).

By presenting himself from the outset as a burden that hampers divine power and wisdom, Job asserts that he possesses an autonomous word. As a creature, he is radically dependent on God's good will. But in the biblical context of the covenant between the Lord Yahweh and the People of Israel, Job feels entitled to demand an answer from God-a response that he will receive at the end of the book.

Job's behavior is enlightening with regard to disability. Whatever its nature, disability is not one-sided: society cannot ameliorate it by making it socially negligible by either systematically excluding anyone who is disabled through isolation or confinement, or by claiming that the disabled are superior - that their disabilities are gifts (i.e. those with Asperger's Syndrome are geniuses, the blind have heightened auditory perception, etc.), which would make disability something to be desired and thus relegate those who are not disabled to their monotonous and ordinary life.

The temptation to force the question of evil back, to prevent it from bursting in, is great. God's prolonged silence provides Job with the opportunity to speak out unexpectedly, to make known his suffering and the problem of its meaning for both himself and everyone else. ${ }^{8}$

While Job's three (and later four) friends who enter into a debate with him have good intentions and want to help Job, they do not truly listen to him in the sense that they refuse to allow him to ask anything that would call into question their traditional understanding and concept of God.

Eschyle, Prométhée Enchaîné, 1220 [980], trans. Paul Mazon, Paris 1931.

8 We see this in chapter 9, when Job wants to assert his right to a fair trial against God. The Lord has strength on his side (9:13). The plaintiff is not heard (9:15). God does not care about the despair of the innocent (9:22). Who can defend man's cause? (9:32). 
As Jean Lévêque shows: "The three visitors are wrong in their manner of being right because they appropriate God by arrogating to themselves the right to speak in his name. Moreover, by standing before God next to Job, they betray their friendship [with Job] and exclude themselves from entering into any dialogue with their suffering [friend] and from possibly helping him. They only know how to repeat the arguments that reassure them, so a theology of suffering cannot develop with them because their experiences and the aporias that arise from them must be eliminated at all costs in order to preserve the coherence of their system." 9

At the beginning of the epilogue to the Book of Job, God drives out the three friends with these words: "You have not spoken of me righteously as my servant Job did" (47:7). The friends did not understand what Job, the protagonist, was experiencing in his incomprehensible suffering-namely, the absolute otherness of divine wisdom that is reflected in the astonishing and unfathomable mystery of the world He created: "I know that you can do all things, and that no purpose of yours can be thwarted. Who is this that hides counsel without knowledge? Therefore I have uttered what I did not understand, things too wonderful for me, which I did not know. Hear, and I will speak. I will question you, and you declare to me" (42:2-4).

From this point forward suffering Job can carry his burden-his maśśa'-without it being an obstacle in his relationship with God. His disability, the malady that has taken him out of society, no longer prevents him from living. The Book of Job concludes with what appears to be a fairytale ending: God blesses him abundantly and gives him everything except... healing. In fact, the Lord literally "restored the prosperity of Job" (42:10). While the text clearly indicates that Job was not healed, he was delivered. This does not necessarily mean that he regained his health, and it would be risky to ascribe this meaning to the text. Interestingly, this restoration occurs when Job prays for his friends- the very same men who had counseled him poorly. In this way, Job is no longer turned inward towards himself, but rather outward

9 J. Lévêque, "Le sens de la souffrance d'après le livre de Job," Revue Théologique de Louvain 6-4(1975): 452-453. The original text in French: "Les trois visiteurs ont tort dans leur manière d'avoir raison car ils annexent Dieu en s'arrogeant le droit de parler en son nom. De plus, en se plaçant pas devant Dieu à côté de Job, ils trahissent l'amitié et s'interdisent à la fois tout dialogue avec celui qui souffre et toute possibilité de médiation. Ils savent uniquement répéter les thèses qui les rassurent, mis avec eux la théologie de la souffrance ne peut progresser, car l'expérience vécue et les apories qu'elle fait surgir doivent s'effacer à tout prix pour que soit préservée la cohérence d'un système." 
Theology of Spirituality towards others, including those with whom he had disagreed. Sickness is no longer an obstacle to Job's prosperity or even happiness. ${ }^{10}$ Job's story recalls something of Jacob's struggle with God (Genesis $32: 23-33)$. At the end of a night of wrestling, a mysterious man, who does not reveal his name, blesses Jacob and gives him a name that would one day be the name of an entire people: Israel. Jacob has been given not only a new name but also a disability, since the unnamed man struck him in the hip while they wrestled. ${ }^{11}$

"When the disability is physical or mental, then the struggle occurs daily. But what should one call this struggle, since the main objective of the one who deals with it is to survive [...] From this point on, Jacob is lame [...] The struggle that occurred in the night will force him to live his life differently. Disability is like that-it makes you stumble into a different, unknown, and difficult existence... The figure of Jacob tells us about what disability is: a struggle throughout the night, a creative

10

F. Mies, "Se plaindre de Dieu avec Job," Études, 10, vol. 411(2009): 363: "Job's response to God goes beyond the confines of his discourse (42:2-6) and extends into to his entire life as narrated in the epilogue. It is not a happy ending: if Job regains fortune and honor, if he is reintegrated into the human family, his dead children remain dead and it would seem that he himself will remained ill. But consoled, he is able to say 'yes' to life once again." The original text in French: "La réponse de Job à Dieu excède les limites de son discours (42,2-6) et s'étend à toute sa vie racontée dans l'épilogue. Ce n'est pas un happy end: si Job retrouve fortune et honneur, s'il est réintégré dans la famille humaine, ses enfants morts restent morts et il semble bien que lui-même soit demeuré malade. Mais consolé, il est capable de redire oui à la vie." The same author takes into consideration this issue in his article: "Job a-t-il été guéri?," Gregorianum, 4, vol. 88(2007): 703-728.

11 H.-J. Stiker, "Le récit mythique du passage du Yabboq," Journal des Anthropologues, nos. 122-123, vol. 3-4(2010): 63: "What I would emphasize in Job's case Jacob is that he fulfills the role of a father of a people, and, therefore, of a founder and leader. The status of this people-a small group (at the time of the Babylonian Exile, the People of Israel were called a "Remnant")—is lowly, which is symbolized by his lameness." The original text in French reads: "Ce que je souligne dans le cas de Jacob c'est qu'il compose la fonction de père d'un peuple, donc de fondateur et de chef et le statut de ce peuple, petit et fait de petits (au moment de l'Exil du peuple d'Israël à Babylone il sera question du «Reste ») dont sa boiterie me paraît le symbole.” A.-M. Gérard, Dictionnaire de la Bible, ed. Robert Laffont, Paris 1989, 567-568: "Let us recall that, from that point forward, the Great Ancestor blessed by God and struck in the flesh in whom the people of Israel recognize themselves personifies in his glories and his miseries all of his descendants by both blood and in spirit." The original text in French: "Retenons que le Grand Ancêtre en qui se reconnaît le peuple d'Israël, ainsi béni de Dieu et frappé dans sa chair, personnifie dès lors avec ses gloires et ses misères toute sa descendance par le sang et l'esprit." 
work to be done despite everything, transformed relationships, the ability to say 'I' in a completely new way." 12

Like Jacob at the end of his wrestling match, Job endures his inTheology of Spirituality firmity, his burden, his maśśa' with an openness to the mystery of otherness and with a blessing. This is one of the many teachings from this Old Testament book that sheds light on the issue of disability and aligns with what this article argues earlier: As necessary as relieving the burdens of those who are disabled, integrating them into society, and adapting the environment to meet their needs may be, it is an illusion to think that disabilities can be eliminated. Disabilities are always a burden that must be carried both by those who experience them and the societies that care for them. Moreover, and above all, disabilities are maśśa' in the sense of a prophetic word, a lesson about otherness that brings together recognition, radical difference, and mystery.

At this point, we can recall Job's holiness, which lies at the heart of his struggle. The Book of Joshua immediately follows the Pentateuch (the first five books of the Bible), which begins with the creation of the world and ends with Moses' death at entrance to the Promised Land, the land of Canaan. The Book of Joshua tells the story of the conquest of the Promised Land, which different peoples had occupied. A succession of armed conflicts, alliances, and massacres takes place on this land. God inspires and guides the conquest, led by the twelve tribes united under the leadership of a charismatic leader. The story ends with the death of Joshua. While the entire text contains some vague historical elements and could be considered a kind of utopian vision ${ }^{13}$ of so-called "success," it is first and foremost a theological account.

In Jewish tradition, Joshua is considered primarily a prophetic book addressed to the Chosen People, who were being tempted to return to idolatry. That which the Chosen People received from God-the

12 D. Hubert, "Handicap et parole de Dieu," Revue d'éthique et de théologie morale 256(2009): 116-117. The original text in French: "Quand il s'agit d'un handicap physique ou psychique, le combat est quotidien, mais que peut-on nommer de lui puisque la grande affaire, c'est de survivre... Désormais, la vie de Jacob est boiteuse... La lutte nocturne va l'obliger à marcher sa vie autrement. Le handicap est ainsi, il vous fait basculer dans une vie différente, inconnue, difficile... La figure de Jacob nous renseigne sur ce qu'est le handicapg. Un combat jusqu'au bout de la nuit, une ouvre de création à faire malgré tout, des liens transformés, une capacité de dire «je» totalement nouvelle."

13 M. Liverani, La Bible et l'invention de l'histoire, Paris 2010, 288. The Book of Judges, which tells the story of this conquest, conveys that these tribes maintained their influence and are still very present. In any case, both the Book of Judges and the Book of Joshua do not convey a historical reality; they are primarily a theological construct. 
Theology of Spirituality

law on Mount Sinai, which had established and set them apart-had called them to a particular mission. In the Book of Joshua, the Chosen People must confront their otherness, the fact that they have been set apart from reality. ${ }^{14}$

"What is the prophetic spirit? It is the test to which the Chosen People were submitted by God in the desert, where they were stripped of what was familiar and not only had to truly listen to Torah, but to also put its teachings into action. In this sense, it is the prophetic reading of the political issues of that time, which makes the history of Israel not a hagiography or a 'nationalist' history, but a 'holy' historythat is, a critical history of oneself and of a people that was written according to moral standards and not according to self-celebration, self-divinization. The notion of holiness must be understood here etymologically based on the word "holy" (kadosh) in Hebrew (קדוֹשוֹ), means "separated," even from oneself." 15

Job is "blameless and upright, one who feared God" (Job 1:1). He experiences his infirmity as unrelated to his history. He is (or at least seems to be) at the point of seemingly contradictory passage into the Promised Land (which was established when Moses received the Law on Mount Sinai) from a land that must be conquered at the cost of enormous sacrifices. In one of his cries of rebellion, he conveys the image of God fighting against him: "He has kindled his wrath against me, and counts me as his adversary. His troops come on together; they have thrown up siegeworks against me, and encamp around my tent" (19:11-12). Job is in the land where God must submit him to the test and trial of purification.

The figure of Joshua (Yehoshua, יהוֹשָעy transliterated into Greek:

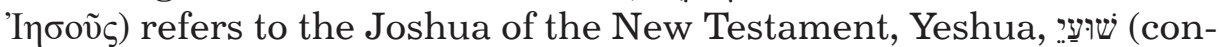
traction) - that is: Jesus. Christ, therefore, bears the name of the

$14 \quad$ P. Haddad, "Terre sainte ou terre de sainteté?," Transversalités 119, vol. 3(2011): 50-51: "God gives Israel the land of Canaan to serve as context in which they must apply the Torah to their lives." In: the original French: "Dieu donne à Israël la terre de Canaan dont la fonction doit servir de champ d'application à la Torah."

15 S. Trigano, "Les guerres de Josué: origine et violence," Pardès, 36, vol. 1(2004): 15. The original text in French: "Qu'est-ce que l'esprit prophétique? La mise à l'épreuve du réel de l'enseignement de la Tora donné dans le désert, l'examen du passage à l'acte. En ce sens, c'est la lecture prophétique de la politique qui fait que l'histoire d'Israël n'est pas une hagiographie, une histoire nationaliste, mais une histoire sainte, c'est-à-dire l'histoire critique de soi, d'un peuple, écrite en fonction de l'exigence morale et non de l'auto-célébration, de l'auto-divinisation. La notion de sainteté doit ici être comprise dans son sens étymologique. Saint, kadosh, veut dire séparé. D’avec soi-même." 
biblical hero. The Gospel of Matthew tells the meaning of this name when the angel appears to Joseph in a dream: "You shall call his name Jesus, for he will save his people from their sins" (1:21). The name Jesus means "He saves." More precisely, the name Yeshua can be broken down into "Ye," which represents God's name, and "shua," which means "a cry for help." Thus, the literal meaning is "God a cry for help." One could then translate this to mean: "Lord help!" or "cry to God, He will save you." 16 The Jesus of the Gospel is indeed the Savior who responds to everyone. He teaches, explains, delivers, heals, and confounds the powerful.

However, the Savior - the Joshua who is supposed to go from victory to victory like his Old Testament namesake-is condemned to suffer and die on the cross. While he is dying, he is mocked: "Save yourself, come down from the cross!" (Mk 15:30; Mt 27:40; Lk 23:37). Christ invites his disciples to share not only in his victory but also his burden: "If any want to become my followers, let them ...take up their cross and follow me" (Mk 8:34; Mt 16:24; Lk 9:23). Jesus invites everyone to carry the burden that he himself has borne. According to Christian tradition, holiness is conformity to Christ the Savior through the grace that comes to us from him. This means that perfection always entails both theologia gloriae and theologia crucis. Otherwise, it is impossible for holiness to include those who are vulnerable, dependent, infirm, and disabled. ${ }^{17}$

For his disciples, Jesus is Joshua the conqueror of the Promised Land. In Christ, they do not initially see Job who carries the weight of his humanity in being isolated, challenged, misunderstood, betrayed, tortured, condemned, and rejected. Before His crucifixion, the disciples see Christ's glory, but not the cross.

16 E. Klein, “עושש," in: A Comprehensive Etymological Dictionary of the Hebrew Language, New York 1987.

17 D. Foyer, "Théologie du handicap, théologie handicapée," Revue d'éthique et de théologie morale 256(2009). "We are unable to think theologically about disability - the existence of an 'evil in excess' that is so revolting and unjustifiable and yet nevertheless is susceptible to the word of God. Should a theology of disability then culminate in the silence that Job or Jesus on Golgotha experienced? I believe that silence is necessary for God to speak, since silence speaks well of God." The original text in French reads: "Nous avons une incapacité à penser théologiquement le fait du handicap, l'existence d'un mal en excès, révoltant et injustifiable en tant que tel, comme pourtant susceptible de dire Dieu. Une théologie du handicap doit-elle alors aboutir au silence, comme dans l'expérience de Job, comme au Golgotha? Je crois que c'est un passage nécessaire pour que Dieu puisse parler, puisque lui seul parle bien de Dieu." 
Theology of Spirituality

The depiction of Jesus on the cross in the Isenheim altarpiece by Matthias Grünewald is undoubtedly one of the most striking representations of Christ in the spirit of Job. In this painting, Jesus' arms are extended and nailed to a branch arched downward due to the heavy weight of his body, which is like one massive wound. His naked flesh recalls an overripe fruit that has, perhaps, already rotted through. This large altarpiece was painted around 1515 for the Antoine monks of the Monastery of St. Anthony who ran a hospital for patients suffering from the bubonic plague and gangrenous diseases. The depiction of Christ recalls the writer Joris-Karl Huysmans' description of Job's body covered un ulcers (2:7): The body looks "pale and shiny, dotted with spots of blood, and bristling like a chestnut-burr with splinters that the rods have left in the wounds; at the ends of the unnaturally long arms the hands twist convulsively and claw the air; the knees are turned in so that the bulbous knee-caps almost touch; while the feet, nailed one on top of the other, are just a jumbled heap of muscles underneath rotting, discolored flesh and blue toe-nails." ${ }^{18}$ The weight of suffering that provokes horror and even disgust reminds us that the Church is responsible for all humanity, even those who seem to be on the brink of degraded humanity. As a result, holiness is both a gift and the act of cooperating with God himself. Grünewald's depiction of Christ erupted in boils is the most human of all. In this image, Christ's ugliness revests the sacred and questions the Faith. ${ }^{19}$

The Church's holiness is measured by the place She gives to those who suffer from all kinds of disability and by the way in which She shares the burden and lives in communion with others. Thus, as Thomas Reynolds, the father of a severely disabled child diagnosed with Asperger's syndrome and bipolar disorder, writes: if Christ suffers, it is not in order to offer himself to the vulnerable as a companion in misfortune, but to call all of creation marked by vulnerability to live as he lived until the very end: to care for each person, welcome others without measure, love, and live in communion. ${ }^{20}$ Paradoxically,

18 J.-K. Huysmans, "The Grünewalds in the Colmar Museum," in: Trois Primitifs, trans. R. Baldick, London 1958.

$19 \quad$ N. Arambasin, "Le corps crucifié," Communications 60(1995): 145. In another artistic medium, we could also mention the work of iconographer Caroll Rosso Cicogna, who includes elements of contemporary artistic expression into her sacred images, thereby expressing the holiness of a renewed vision within the midst of organized chaos.

20 "The redemptive nearness of God to human vulnerability, a nearness of solidarity and brokenness, that does not undo or fix such brokenness, paradoxically 
Job emerged from his limitations and received God's hospitality by welcoming the incomprehensible mystery of his maśśa'.

\section{Bibliography:}

1. Arambasin, N. "Le corps crucifié." Communications 60(1995): 141-154.

2. Eschyle, Prométhée Enchaîné, 1220 [980]. Translated by Paul Mazon. Paris 1931.

3. Foyer, D. "Théologie du handicap, théologie handicapée." Revue d'éthique et de théologie morale 256(2009): 147-157.

4. Gérard, A.-M. Dictionnaire de la Bible. Edited by R. Laffont. Paris 1989.

5. Haddad, P. "Terre sainte ou terre de sainteté?" Transversalités 119. Volume 3(2011): 45-51.

6. Holy Bible: New Revised Standard Version Catholic Edition (NRSVCE). Oxford 2001.

7. Hubert, D. "Handicap et parole de Dieu." Revue d'éthique et de théologie morale 256(2009): 111-126.

8. Huysmans, J-K. "The Grünewalds in the Colmar Museum." In: Trois Primitifs. Translated by R. Baldick. London 1958.

9. Klein, E. A Comprehensive Etymological Dictionary of the Hebrew Language. New York 1987.

10. Lambert, G. "Mon joug est aisé et mon fardeau léger." Nouvelle Revue Théologique (NRT) 9. Volume 77(1955): 963-969.

11. Lévêque, J. "Le sens de la souffrance d'après le livre de Job." Revue Théologique de Louvain 6-4(1975): 438-459.

12. Liverani, M. La Bible et l'invention de l'histoire. Paris 2010.

13. Maggi-Germain, N. "La construction juridique du handicap." Droit social 12(2002): 1092-1100.

14. Mies, F. "Job a-t-il été guéri?" Gregorianum 88(2007): 703-728.

15. Mies, F. "Se plaindre de Dieu avec Job." Études 10. Volume 411(2009): 353-364.

16. Reynolds, T. E. Vulnerable Communion: A Theology of Disability and Hospitality. Grand Rapids 2008.

17. Sanchez, P. Justice pour les personnes handicapées. Grenoble 2014.

18. Stiker, H.-J. "Le récit mythique du passage du Yabboq." Journal des Anthropologues 122-123. vol. 3-4(2010): 49-66.

19. Trigano, S. "Les guerres de Josué: origine et violence." Pardès, 36. Volume 1(2004): 13-22. 